Article

\title{
The Effectiveness of Russian Government Policy to Support SMEs in the COVID-19 Pandemic
}

\author{
Elena Razumovskaia ${ }^{1,2, *}$, Larisa Yuzvovich ${ }^{2}$, Elena Kniazeva ${ }^{2}$, Mikhail Klimenko ${ }^{3}$ and \\ Valeriy Shelyakin 4 \\ 1 Department of Finance, Money Circulation, and Credit, Ural Federal University Named after the First \\ President of Russia B.N., Yeltsin, 19 Mira St., 620002 Yekaterinburg, Russia \\ 2 Department of Finance, Money Circulation, and Credit, Ural State University of Economics, 8 Marta St., \\ 620144 Yekaterinburg, Russia; larisayuzvovich@yandex.ru (L.Y.); kniazeva.elena@bk.ru (E.K.) \\ 3 The Sverdlovsk Region Legislative Assembly, 10 Borisa Yeltsina St., 620031 Yekaterinburg, Russia; \\ mihhailklimenko@yandex.ru \\ 4 Territorial Fund of Compulsory Medical Insurance of Sverdlovsk Region, 54 Moskovskaya St., \\ 620102 Yekaterinburg, Russia; shelyakin49@mail.ru \\ * Correspondence: razumovskaia.elena@yandex.ru
}

Received: 20 August 2020; Accepted: 12 November 2020; Published: 19 November 2020

\begin{abstract}
This study was aimed at developing a cognitive-econometric model for assessing the effectiveness of the current governmental policies to support enterprises in Russia in the context of pandemic propagation. Using the Granger test and correlation analysis, we formed a system of key indicators that characterizes the economic development of SMEs (small and medium-sized enterprises) in Russia. Based on the revealed causal relationships and correlation coefficients, a model describing the impact of public policy support instruments on SME economic development was built using cognitive modeling. By means of the additive convolution method, the correlation coefficient between the Russia Small Business Index (RSBI) and the COVID-19 prevalence rate was used to predict the 2020 year-end RSBI value. Regarding the RSBI index forecast, the effectiveness of instruments of the state support for SMEs was evaluated. It was determined how much these indicators of the anti-crisis package of measures should change to increase SMEs' business activities. The developed cognitive model can be utilized by private and governmental institutions to continuously monitor the effectiveness of public policies that support SMEs. It can also be used as a preventive indicator to evaluate the impact of the anti-crisis measures during pandemics and in the case of other exogenous risks threatening SMEs. The originality of the research results was determined by the econometric methods applied to empirically assess the effectiveness and degree of impact of governmental measures on the operation of SMEs under conditions of uncertainty.
\end{abstract}

Keywords: SMEs; Russia; COVID-19; development; entrepreneurship; effectiveness; anti-crisis policy measures; government support

\section{Introduction}

\subsection{Features of SME Development Prior to the COVID-19 Pandemic}

Economic efficiency is largely determined by the combination of business activities of SMEs. SMEs are one of the key drivers in the socio-economic development of a country and its regions, as they ensure the formation and emergence of permanent new jobs. Therefore, they serve as a guarantee of the population's income and ability to pay [1-5]. Additionally, sustainable development and effective functioning ensure and maintain a healthy competitive balance of entrepreneurial activities in the business environment. Innovation is another essential advantage of SMEs, since this sector of economic 
business activity patents 16 times more new developments compared to large business per those employed in business [6].

Basically, multiple studies confirm a direct positive relationship between the level of people's well-being in the country, the rate of national economic development and the efficiency of the SME sector $[1,2,5,7]$. SMEs make up 50-60\% of the GDP of developed countries. Thus, in Great Britain, it is $51 \%, 53 \%$ in Germany, $60 \%$ in Finland and $63 \%$ in the Netherlands [8,9]. In terms of the share in economic development, the indicators of business activities in the Russian SME sector are far behind other countries. In Russia, this figure is slightly above $20 \%$ of the GDP [10]. The above data indicate that SMEs take a leading position in ensuring economic growth rates in developed countries, and the low level of development in Russia requires the creation of conditions for unlocking their potential.

In recent years, conditions have been created at the institutional level to ensure the innovative development of the Russian economy and its structural diversification [11]. This, in turn, formed the foundation of the most favorable conditions for entrepreneurial initiative. In accordance with the passport of the national project for the development of SMEs, there is an aim to increase the contribution of this sector to the economy to $32.5 \%$ by 2024 [11]. At the same time, the Strategy for the Development of Small and Medium-Sized Businesses from 2016 to 2024 regulates an increase in the contribution of the SME sector to the economy of up to $40 \%$ through concessional financing, simplified taxation, etc. [12].

The availability of finance required for development and growth is one of the most common and significant problems in SME functioning. For Russian small and medium-sized enterprises, the real rate on loans with a maturity of more than one year reached its minimum by the end of 2019 and amounted to $10.33 \%$ [13], which sharply narrows the possibilities of borrowing at the current levels of marginality in most types of activities. However, for comparison, European entrepreneurs have the opportunity to take loans at rates that in real terms are close to zero [14]. At the end of 2015, Russia launched a concessional lending program for small and medium-sized businesses [15] and since 2019, SME support has received the status of a national project [16]. But the drop in the number of SMEs coincided with the Central Bank of the Russian Federation (CBRF) campaign against cashing out in the non-banking sector, as well as with the Federal Tax Service's efforts to identify defaulters.

The high level of tax burden is another destructive factor in the SME development in Russia. According to PwC [17], Russia is among the countries with the highest tax burden-7\% higher than the global average. It is paradoxical that the tax burden level in the country does not correspond to the labor productivity level, which is significantly lower than in developed countries. This means that the current tax policy mainly performs a fiscal function and almost does not perform another important function for the business environment-a stimulating one. As a result, there is a low share of SMEs in the economy and since 2016 the number of small and medium-sized enterprises has been decreasing by $6-10 \%$ annually. Over the entire period from 2016 to the beginning of 2020, about 50,000 SMEs ceased to exist [18].

\subsection{Development of SMEs during the COVID-19 Pandemic}

From February 2020, the Russian business environment was affected by significant negative factors: the rapid propagation of the COVID-19 pandemic and its detrimental impact on the global economy. This, in turn, provoked a collapse in oil prices on the world energy market, which caused waves of ruble devaluation. Because of the imposed restrictions against the background of the spread of coronavirus infection, demand began to fall and business activities slowed down. In April 2020, the SME business activity index fell to its lowest values since 2014. In January 2020, this index reached 51.4 points, in March it was 45 points and in April it was 38.5 points [19].

SMEs have shown a kind of anti-record in sales. Revenue fell by $78 \%$ of respondents, and $60 \%$ of entrepreneurs expect further revenue decline in the near future. At the same time, a decline in sales in the SME segment has been observed since the end of 2019 [20]. By the end of 2020, we can expect an unemployment rate of $8 \%$, and even up to $10 \%$ of the economically active population in the worst case [21]. According to leading experts, during the period of a total pandemic and forced isolation 
in Russia, about $11 \%$ of SMEs suffered, which at first glance does not seem to be a catastrophic level of threat [22]. However, considering that the reduction in turnover in some sectors of the economy provokes a multiplier effect on related industries, an additional $64.2 \%$ of small and medium-sized firms may subsequently close, which approximately comprises 3.4 million companies [23]. Industries that may suffer from the multiplier effect account for almost $77 \%$ of the total turnover of the SME sector [22]. Thus, a catastrophic scenario of a 50-60\% reduction in turnover in the SME sector could lead to a GDP contraction by about $10 \%$ in the second quarter of 2020 [10]. The current circumstances require significant government support for SMEs.

By virtue of their performance peculiarities, small and medium-sized businesses are especially vulnerable to the negative impact of the COVID-19 pandemic on economic relations. This is conditioned by the radical transformation of consumer habits because of the introduced measures of social distancing; fear of being infected with the virus; decreased purchasing power due to a decrease in the level of personal income as a result of a reduction in wages or dismissals, etc. Such effects of measures to counter the pandemic propagation are more destructive for small and medium-sized enterprises [24-27]. Therefore, in the context of the pandemic spread and the disruption of the natural conditions for doing business, ensuring sustainability has ceased to be a theoretical task. SMEs are faced with the fragility of the vital systems on which they rely [24]. The corporate governance system of enterprises has proven its inability to be flexible and responsive in a rapidly changing environment, when ten days of delay can result in a fourfold increase in the number of infected people and intensify the destabilization of business and society [28]. In addition to achieving sustainability in supply chains, it is becoming more important to ensure balanced business operations. In the short term, this implies a considerable reduction in the level of expenditures, the use of mainly own financial resources and, in some cases, support from the state. Today, business survival and preservation have become the main priority of SMEs' corporate governance [28], while business prosperity and growth are postponed into the long term. The detrimental impact of the COVID-19 spread on SMEs also brings the non-market aspects of corporate business strategy to the fore. Sustainable systems can only be created through collaboration both directly between companies and between SMEs and government agencies. To date, anti-crisis supporting measures in connection with the coronavirus pandemic have already affected $13 \%$ of Russian small and medium-sized enterprises, $22 \%$ of SMEs are in the process of receiving support measures and $40 \%$ plan to receive some kind of support [29].

The most demanded measures to support SMEs were a tax payment deferral with regard to all taxes, excluding VAT, for the next six months [30], a loan deferral for the next six months [31] and an insurance premium holiday for the next 6 months [32]. The practical implementation of the anti-crisis government support system has unconditionally yielded its fruit. As early as May 2020, business turnover grew by $17 \%$ against the period of self-isolation and almost approached the February 2020 values, but decreased by $18 \%$ in annual comparison [33]. Up to $20 \%$ of Russian SMEs are characterized by unprofitable activities, being on the verge of bankruptcy, while for large enterprises this figure is only $7 \%$ [34].

This study is aimed at determining the effectiveness and nature of the impact of the anti-crisis government support system for SMEs in Russia during the period of total quarantine due to the spread of COVID-19 infection. The basic key factors of the destructive development of SMEs during the total quarantine were identified and a preliminary forecast of the 2020 year-end business activities of SMEs was carried out without taking into account governmental organizational measures to support entrepreneurs. The causality of the impact of the public policy support instruments on SMEs' operations in current conditions was econometrically substantiated. The effectiveness of public policy instruments that support SMEs was assessed with regard to the forecast of the Russia Small Business Index (RSBI) until the end of 2020, and recommendations for increasing their effectiveness were substantiated.

\section{Literature Review}

In the scientific literature, SMEs are mainly understood as entrepreneurial structures with a number of employees of less than 250 [35]. Currently, they are the backbone of every economy across 
the globe. According to [36], more than $98 \%$ of the totality of formal and informal business structures in different countries are SMEs. Destabilization of the development of these business entities will negatively affect the macroeconomic and social indicators of a country's economy $[1,2,6]$. However, it should be noted that previous studies examining the business effects of previous pandemics, and in particular, their impact on SMEs, are extremely limited. As a rule, scholars studied the impact of epidemics in general on the development of the national or global economy.

It should be noted that there is a rather limited number of publications in the scientific literature regarding the study of the destructive impact of the pandemic propagation on the performance of business structures. The impact of the pandemic on SMEs' operations has generally been studied in terms of the social and economic consequences of the largest global epidemics over the past 100 years. One of the largest pandemics in human history occurred in the late 1910s and early 1920s—Spanish influenza—also known as "Spanish flu" [37]. Almost four decades later, in the winter of 1957, there was an Asian flu epidemic in China [38]. It became the largest one since the Spanish flu. Eleven years later, another pandemic began - this time it was caused by the Hong Kong flu. People got sick from a virus that evolved from the Asian flu. The swine flu epidemic swept the world in 2009 [38,39]. The Ebola virus has been known since the mid-1970s and is associated with fruit bats [39]. However, it became internationally "famous" in 2014 when a fever epidemic began in West Africa in February that year [39]. When studying the impact of a pandemic spread on the economy, as a rule, scholars focused on determining a system of macroeconomic indicators, for example, GDP and its variations in the process of aggravating the situation with the course of a pandemic and the introduction of social distancing and self-isolation measures [38-40]. Additionally, scholars are most commonly occupied with determining and forecasting social [25,39,41,42] and economic [39-44] costs resulting from a pandemic. Attention was focused on different levels of severity of the effects of the pandemic progression $[43,45,46]$, its impact on market supply and demand $[40,45]$, changes in the number of hours worked [40] because of the requirement of isolation and fear of being infected, etc. The effects of government measures to halt the infection ingress rate on trade supply chains and on the development of international trade in general were studied in detail $[45,47]$. Additionally, the various effects of the pandemic spread were studied depending on the sphere of entrepreneurial activity $[43,48-50]$. Reasons were given for benefits and losses from an economic viewpoint, for example, in the service sector [48], the pharmaceutical industry [49] and the food industry [50]. The most affected spheres of economic activity in the context of a pandemic and social distancing were substantiated. In this aspect, the possible economic losses of countries were also studied, depending on the level of economic development and peculiarities of the institutional environment $[26,40,46]$, the level of social security and financing of the health care system [40,51], people's law abidance [40], etc.

Forecasting the dynamics of SARS-CoV-2 [52] became the most common empirical approach in studying the impact of the pandemic on economic processes, which served as a starting point for researchers in the modern conditions of the spread of the COVID-19 pandemic. Scholars used an identical approach to forecast the time series of the epidemic propagation to determine the degree of influence and peculiarities of economic development [46]. Macroeconomic forecasting models for the development of the global economy using the computable general equilibrium (CGE) model have gone mainstream. These models were adapted by scholars when studying the impact of the Ebola epidemic spread in West Africa in 2014 on the level of global and regional economic development [53]. Findings from the study indicate that the largest economic impact of SARS is related to overall GDP and investment $[40,46,54]$. In this aspect, it is also interesting to use scenario modeling based on the mortality rate forecast [55] by determining the computable general equilibrium (CGE) within the economy of one country and exemplified by separating the consequences of the influence on twelve sectors of the UK economy.

However, it should be stated that earlier studies were based on considerations of the effects of the pandemic impact only at the level of macroeconomic indicators with a clear correlation between the mortality rate and the economic impact of the pandemic. However, the consequences at the 
microeconomic level remained outside the attention of economists. In addition, the duration of the course of earlier epidemics was characterized by a relatively short period [39]. As evidenced by the data, the COVID-19 pandemic differs significantly from earlier studied experiences. First of all, the duration of its propagation [40] and a high level of risk of uncertainty [43,56,57] are its distinctive features. The current pandemic has simultaneously destructively affected both demand and market supply, in the absence of any correlations between the impact of the pandemic on the economy and the mortality rate as a consequence of the viral shedding and transmissibility [58].

In view of this, there has been a lot of scientific publications about the impact of the COVID-19 pandemic on SMEs. Most of them are devoted to substantiating the readiness and vulnerability of medium and small enterprises to operate in the face of a shock in supply and demand, a reduction in the labor force, etc. $[26,27,37,39,50]$. The importance of studying the consequences of the coronavirus pandemic for SMEs is primarily substantiated by the fact that, unlike large businesses, SMEs are characterized by more limited resources and structural features [26,37]. SMEs are more susceptible to the consequences of the negative impact of the viral shedding and transmissibility, and the implementation of government measures to prevent its propagation [59,60]. The particular vulnerability of SMEs to the consequences of the pandemic is explained by the limited capacity and volume of resources to support life in the harsh business environment [50]. In general, most scholars agree that limited financial resources $[61,62]$ and the possibilities of capitalizing external financial resources $[26,37,50]$ are the fundamental factors of the greatest vulnerability of SMEs during a pandemic.

It is crucial in this aspect that such environmental shocks provoke a high level of strategic uncertainty in the functioning of small and medium-sized businesses $[26,54,63]$. Scholars focus on the advantages of centralized corporate management systems $[26,64]$, since in the context of a health system crisis, the ability of an enterprise to mobilize financial, technological and human resources in the shortest possible time is the most important factor for SMEs' survival - this is an advantage of centralized systems [65]. As noted, the COVID-19 pandemic brings the non-market aspects of corporate strategy to the fore. The priorities of SME business leaders are changing, as long-term measures to ensure sustainability that are necessary for survival in the next ten years gain paramount importance [59]. According to scholars, two clear trends have formed within the transformation of corporate governance priorities. The first is a significant acceleration of the transition to digital channels and platforms [66]. Traditional organizations will have to fully participate in this transition to avoid the risk of being disrupted by digital companies. The second is the transformation in the organization of hybrid learning:

Combining the capabilities of artificial intelligence and human thinking [66];

Employing a more effective approach to manage amendments [67];

Relying on the diversity of staff to increase sustainability and using open innovation [68-71].

With this background, today, scholars focus on the analysis of support measures taken by the governments of various countries [59,60].

Most scholars examine the effectiveness of measures taken by governments to help SMEs cope with liquidity shortages [61,62] caused by the spread of the COVID-19 virus and the failure to respond adequately.

It is worth noting that, as a whole, so far, scholars have considered and described the anti-crisis package to support SMEs in different countries, such as tax holidays $[25,48,54,57,58]$; moratorium on conducting business audits [58,59]; insurance premium reduction and holidays [58,59]; credit holidays [54,58-63]; moratorium on bankruptcy filings initiated by creditors [58,59]; public funding $[54,55,58,59,62,64-66]$ and so on. As evidenced by the results of research, the studied state support system provides slow but fairly stable life support [59]. However, such exogenous risk implies a high level of uncertainty. In the face of a shock in supply and demand, the state support should be aimed at activating the introduction and development of open innovation in the SME sector. Only this approach can ensure the balanced development of this sector of the economy in the current 
situation. Consequently, the primary focus should be on maintaining business continuity to save as many jobs as possible and provide the basis for a smoother and faster recovery by preventing permanent closures and keeping firms from entering the informal economy. This approach enables us to not only to comprehensively analyze the problems of entrepreneurship, but also to develop the most effective mechanisms of state support for SMEs. Support measures developed by states should be based on clear goals of economic policy, be systemic and also take into account long-term priorities for business development. They should be oriented toward the formation of a system of "state-population-business" interactions, making it more advanced and aimed at development.

\section{Methods and Materials}

Our research assumed the formation of three samples of indicators: (1) indicators that characterize the implementation of government measures aimed at the development of small and medium-sized businesses (G1-G9); (2) other indicators of economic activity affecting the state of small and medium-sized businesses (X1-X11), including the COVID-19 spread intensity indicator; (3) the resulting indicator of SME development $(Y)$. Using this system of indicators, the direct and indirect influence of government measures to support small and medium-sized businesses on the level of SME development was simulated. Their effectiveness during a pandemic was also assessed under the influence of the COVID-19 spread intensity indicator.

The list of statistical indicators used in this study to simulate the impact of the government measures on the development of SMEs is given in Table 1. These are indicators that quantitatively reflect the implementation degree for each instrument of state regulation of small and medium-sized businesses stipulated by [72,73] for the period of the COVID-19 pandemic. Apart from the indicator of subsidy volumes, the block of public funding is supplemented by investment volumes as an additional source of financing in the context of COVID-19. The statistical significance of the influence of these indicators on the development of small and medium-sized businesses was proved during the research using the Granger test and the calculated correlation coefficients.

Table 1. Indicators of the implementation of government measures aimed at the development of SMEs.

\begin{tabular}{cll}
\hline $\begin{array}{c}\text { Type of Government } \\
\text { Support }\end{array}$ & \multicolumn{1}{c}{ Indicator } & $\begin{array}{c}\text { Symbolic Notation } \\
\text { of the Indicator }\end{array}$ \\
\hline \multirow{2}{*}{ Tax support [74] } & $\begin{array}{l}\text { The amount of deferred payments (installment liabilities) } \\
\text { and restructured debt, million RUB, which includes taxes } \\
\text { and fees payable, as well as fines and tax sanctions payable }\end{array}$ & G1 \\
\cline { 2 - 3 } & Number of on-site tax audits, units & G2 \\
\cline { 2 - 3 } & Number of office tax audits, units & G3 \\
\hline & $\begin{array}{l}\text { The amount of premium income from compulsory social } \\
\text { insurance, million RUB }\end{array}$ & G4 \\
\hline Credit support [75] & $\begin{array}{l}\text { Interest on loans to support small and medium-sized } \\
\text { businesses, \% per annum }\end{array}$ & G5 \\
\hline sdministrative & $\begin{array}{l}\text { The number of enterprises that went bankrupt on the } \\
\text { creditors' initiative, units }\end{array}$ & G6 \\
\hline \multirow{2}{*}{$\begin{array}{l}\text { Public funding [77] } \\
\text { fhe volume of subsidies allocated from the federal budget } \\
\text { for government support for small and medium-sized } \\
\text { businesses, billion RUB }\end{array}$} & $\begin{array}{l}\text { The volume of investment in fixed assets of small and } \\
\text { medium-sized businesses at the expense of budget funds, } \\
\text { billion RUB }\end{array}$ \\
$\begin{array}{l}\text { The volume of investment in fixed assets of small and } \\
\text { medium-sized businesses at the expense of state } \\
\text { non-budgetary funds, billion RUB. }\end{array}$ & G7 \\
\hline
\end{tabular}


The research is aimed at identifying causal relationships, building a model of the influence of state support instruments (indicators G1-G9) in the retrospective period and is based on the assumption that the nature of the impact of state support instruments exerted on the SME development indicators will remain during the pandemic.

Since there are no data on SME development indicators for 2020, per annum interest rates on loans to support the economy during the COVID-19 pandemic are not examined among the indicators of credit support. However, this drawback is leveled by the presence of the indicator G5 in the study, which directly affects the possibilities of attracting borrowed funds by small and medium-sized businesses.

The Russia Small Business Index was adopted as the resulting indicator of SME development, it was calculated on the basis of the results of 2300 surveyed companies (covering $63 \%$ of the total turnover of small and medium-sized businesses in Russia) in 23 regions [19]. In addition, this index is closely correlated with the dynamics of the country's GDP (the correlation coefficient between the RSBI and GDP in current prices amounts to $81.08 \%$ ), which indicates its representativeness in assessing small and medium-sized businesses in Russia. This index characterizes both the current economic state of SMEs (through the income indicator, which is its sub-indicator), and the prospective one (through the sub-indicators of investment volumes, staffing and availability of funding) [19]. The practicability of using the RSBI as a resultant indicator of the development of small and medium-sized businesses is also confirmed by scientific research [78-81].

Other indicators (in addition to indicators of state regulation) that affect the development of small and medium-sized businesses were also used:

(1) the number of SMEs, units (X1);

(2) the number of employees of small and medium-sized enterprises, thousand people (X2);

(3) the volume of SME turnover, billion RUB (X3);

(4) the volume of production costs of small and medium-sized businesses, billion RUB (X4);

(5) the amount of net profit of SMEs, billion RUB (X5);

(6) the amount of equity capital of SMEs, billion RUB (X6);

(7) the amount of borrowed and attracted capital of SMEs, billion RUB (X7);

(8) the volumes of private investment in fixed assets of SMEs (foreign investment, funds of organizations and population), billion RUB (X8);

(9) the intensity of COVID-19 propagation (X9);

(10) producer price index, \% (X10);

(11) consumer price index, \% (X11).

The specified system of indicators was determined based on the analysis of the relevant literature sources [1,2,6,82-84], and it was supplemented with the COVID-19 spread intensity indicator, since this parameter has a significant destabilizing effect on the development of SMEs and the entire economy around the world.

These indicators have an impact on the Russia Small Business Index (RSBI), which is confirmed by the Granger test (see Table 2). In addition, we used the Granger test to confirm the statistical significance of the impact of government support tools on the RSBI value (indicators G1-G9). The calculation of paired linear correlation coefficients between the indicators of SME development and the indicators of government support is possible as there is a linear relationship between them for the period under study. 
Table 2. The causalities between the indicators of SME economic development and indicators of government support that are statistically significant according to the Granger test at $p=0.05$.

\begin{tabular}{cccc}
\hline Null Hypothesis & Prob. & Causal Direction & Paired Correlation Coefficients \\
\hline G1 does not Granger cause $X 5$ & 0.003 & $G 1 \rightarrow X 5$ & 0.852 \\
G2 does not Granger cause $X 5$ & 0.002 & $G 2 \rightarrow X 5$ & -0.888 \\
G3 does not Granger cause $X 5$ & 0.004 & $G 3 \rightarrow X 5$ & -0.847 \\
G4 does not Granger cause $X 5$ & 0.003 & $G 4 \rightarrow X 5$ & -0.856 \\
G5 does not Granger cause $X 7$ & 0.003 & $G 5 \rightarrow X 7$ & -0.862 \\
G6 does not Granger cause $X 1$ & 0.006 & $G 6 \rightarrow X 1$ & -0.819 \\
G7 does not Granger cause $X 7$ & 0.000 & $G 7 \rightarrow X 7$ & 0.947 \\
G8 does not Granger cause $X 7$ & 0.000 & $G 8 \rightarrow X 7$ & 0.966 \\
G9 does not Granger cause $X 7$ & 0.005 & $G 9 \rightarrow X 7$ & 0.838 \\
X1 does not Granger cause $X 2$ & 0.006 & $X 1 \rightarrow X 2$ & 0.809 \\
$X 1$ does not Granger cause $X 3$ & 0.010 & $X 1 \rightarrow X 3$ & 0.772 \\
X1 does not Granger cause $X 4$ & 0.009 & $X 1 \rightarrow X 4$ & 0.782 \\
$X 2$ does not Granger cause $X 3$ & 0.002 & $X 2 \rightarrow X 3$ & 0.892 \\
X2 does not Granger cause $X 4$ & 0.002 & $X 2 \rightarrow X 4$ & 0.884 \\
X3 does not Granger cause $X 5$ & 0.000 & $X 3 \rightarrow X 5$ & 0.967 \\
$X 4$ does not Granger cause $X 5$ & 0.000 & $X 4 \rightarrow X 5$ & -0.951 \\
$X 5$ does not Granger cause $X 6$ & 0.006 & $X 5 \rightarrow X 6$ & 0.817 \\
$X 5$ does not Granger cause $Y$ & 0.000 & $X 5 \rightarrow Y$ & 0.963 \\
$X 6$ does not Granger cause $X 3$ & 0.004 & $X 6 \rightarrow X 3$ & 0.839 \\
X6 does not Granger cause $X 5$ & 0.006 & $X 6 \rightarrow X 5$ & 0.817 \\
$X 6$ does not Granger cause $Y$ & 0.001 & $X 6 \rightarrow Y$ & 0.924 \\
$X 7$ does not Granger cause $X 3$ & 0.000 & $X 7 \rightarrow X 3$ & 0.961 \\
$X 7$ does not Granger cause $X 5$ & 0.001 & $X 7 \rightarrow X 5$ & 0.925 \\
$X 7$ does not Granger cause $Y$ & 0.005 & $X 7 \rightarrow Y$ & 0.834 \\
$X 8$ does not Granger cause $X 6$ & 0.006 & $X 8 \rightarrow X 6$ & 0.812 \\
$X 8$ does not Granger cause $X 7$ & 0.000 & $X 8 \rightarrow X 7$ & 0.994 \\
$X 9$ does not Granger cause $Y$ & 0.000 & $X 9 \rightarrow Y$ & 0.997 \\
$X 10$ does not Granger cause $X 4$ & 0.005 & $X 10 \rightarrow X 4$ & 0.831 \\
X11 does not Granger cause $X 3$ & 0.004 & $X 11 \rightarrow X 3$ & \\
$Y$ does not Granger cause $X 1$ & 0.005 & $Y \rightarrow X 1$ & \\
\hline
\end{tabular}

The correlation analysis carried out in this study and the use of the Granger causality test showed that among the indicators of the COVID-19 spread intensity (the number of infected people in Russia; the number of infected people in the world; the ratio of cases to those recovered in Russia; the ratio of cases to those recovered in the world; mortality rate in Russia; mortality rate in the world; duration of quarantine in Russia; duration of quarantine in the world; severity of quarantine measures in Russia) [85-87], a significant impact on the dynamics of the RSBI is exerted by:

(1) Duration of quarantine in the world $\left(t_{1}\right)$, days. The first country to introduce quarantine was China-since 23.01.2020, restrictions have been introduced that affect small and medium-sized businesses around the world. Therefore, 23 January 2020 is the "zero" point from which the duration of quarantine in the world is counted for the purposes of this study. The influence of this indicator on the level of business activities of small and medium-sized enterprises in Russia is conditioned by the mood of panic of the population, the limitation of passenger and transport traffic, the increase in the cost of transporting goods and a decrease in foreign trade. The value of the correlation coefficient between the quarantine duration in the world and the RSBI is -0.97 ;

(2) The duration of quarantine in Russia $\left(t_{2}\right)$, expressed in days, is the duration of the non-working day regime. The impact of quarantine is expressed by a decrease in domestic demand for goods and services; decrease in labor productivity as a result of teleworking (according to [40], teleworking leads to a $5 \%$ decrease in labor productivity). The value of the correlation coefficient between the duration of non-working days in Russia and the RSBI is -0.96 . 
With regard to the significant impact of indicators $t_{1}$ and $t_{2}$ on the business activities of small and medium-sized enterprises in connection with the spread of COVID-19, an integral indicator of its intensity was calculated (indicator X9). The integral indicator was computed. proceeding from the values of the constituent indicators and the coefficients of their significance: $k_{i}=\frac{r_{i Y}}{\sum_{i=1}^{n} r_{i Y}}$, where $k_{i}$ is the coefficient of significance of the $i$-th indicator that formed the integral indicator $X 9$; $r_{i Y}$ is the value modulo of the paired correlation coefficient between the $i$-th indicator and $Y ; \sum r_{i Y}$ is the sum of the paired correlation coefficient modulo between the indicators included in $X 9$ and $Y$, $n=2$. Then $X 9=k_{1} \times t_{1}+k_{2} \times t_{2}$, where $t_{1}$ is the duration of quarantine in the world, days; $t_{2}$ is the duration of non-working days in Russia, days; $k_{1}$ and $k_{2}$ are coefficients of significance of indicators $t_{1}$ and $t_{2}$, respectively. The calculation of the integral indicator X9 became possible because of the identical destabilizing nature of the influence of the indicators $t_{1}$ and $t_{2}$, which is manifested in the RSBI dynamics.

At certain stages of the research, different time spans of variable values were used. This is caused by the periods of the relevant data publication. Thus, there are official data for 2008-2018 concerning the indicators of state regulation of small and medium-sized businesses (G1-G9) and indicators of economic activity affecting the development of small and medium-sized businesses (X1-X8, X10-X11). However, quarterly calculations of the RSBI, which is the resulting indicator, started in 2014, and since January 2020 it has been calculated monthly. The calculation of the COVID-19 spread intensity indicator (X9) is possible for the period of January-April 2020. This article uses the maximum possible time spans for all indicators.

Therefore, the annual values of indicators G1-G9, X1-X8, X10-X11 and $Y$ for 2014-2018 comprised the statistical base of the study [74-88]. On their basis, the influence of state regulation instruments on the development of small and medium-sized businesses was simulated. Additionally, monthly data for January-April 2020 for the $Y$ indicator and $X 9$ sub-indicator were used to assess the impact of the COVID-19 pandemic on SMEs' development. With regard to the above, this study proceeds from the fact that the nature and strength of the influence of state support instruments on SMEs' development identified for the period of 2014-2018 will remain unchanged in the period of the pandemic.

The use of different time ranges for indicators while constructing a cognitive model made it possible to simulate the impact of the maximum number of factors on the development of SMEs based on retrospective data of indicators G1-G9, X1-X8, X10-X11 and $Y$ and the impact of the COVID-19 pandemic based on real-time data for indicators $t_{1}$ and $t_{2}$ and $Y$. At the same time, the different time ranges, different level of detail and different dimensions and units of measurement for indicators do not reduce the reliability of the findings, since the study did not imply the construction of an integral empirical model based on the values of these indicators.

The effectiveness of the government support tools was assessed by means of impulse modeling, according to which changes in the resulting indicator $(Y)$ were evaluated when the indicators G1-G9 changed by $1 \%: Y_{i}=G_{i} \times r_{G_{i} X_{j}} \times r_{X_{j} X_{k}} \times \ldots \times r_{X_{l}} Y$, where $\hat{Y}_{i}$ is the change in indicator $Y$ under the influence of an impulse, \%; $\hat{G}_{i}$-is the change in $G_{i}$ by $1 \%$ relative to the baseline, $\% ; r_{G i X j}, r_{X j X k}$, $r_{X I Y}$ are values of paired correlation coefficients between indicators $G_{i}-X_{j}, X_{j}-X_{k}, X_{l}-Y ; X_{j}$, $X_{k}, X_{l}$ are indicators that reflect the chain of influence of $G_{i}$ on $Y$ (as confirmed by Granger's test; $\left.G_{i}=\{G 1, \ldots, G 9\}\right)$. The values of the indicators for 2018 were assumed as the baseline.

\section{Results}

The results of verifying the indicators of economic development of SMEs and indicators of government support for the presence of causal relationships according to the Granger test are presented in Table 2. The table shows statistically significant causalities between the indicators at $p=0.05$ in the absence of a time lag.

The significance of the causalities given in Table 2 is also confirmed by the values of $\operatorname{Prob}<0.05$ and correlation coefficients $>0.75$. 
Based on the data of Table 2, it was determined that indicator X1 is an indirect indicator of the entrepreneurship efficiency: the number of enterprises increases with efficient activities; enterprises become bankrupt and liquidated with inefficient activities. This indicator depends on the efficiency of the small and medium-sized business segment, signified by the RSBI $(Y)$, and the intensity of the government support implementation aimed at a moratorium on bankruptcy filings initiated by creditors, signified by indicator G6. An increase in indicator G6 (the number of bankruptcies initiated by creditors) leads to a decrease in X1. In turn, indicator X1 affects the number of jobs, i.e., the number of employees (indicator X2).

The number of enterprises has a significant impact on the turnover (indicator X3) and production costs (indicator X4) of enterprises that generate net profit (indicator X5); this impact is also confirmed by the Granger test.

In addition to the number of enterprises, the indicator of turnover and expenses is influenced by the number of employees (X2), on the one hand, an increase in their number leads to an increase in wage costs and, on the other, it results in an increase in income, as well as by the amount of equity capital (X6), and by the amount of borrowed and attracted capital (X7), which are sources of financing and generating income for enterprises, but are payable and their increase leads to an increase in expenses. These are non-production costs; therefore, indicators X6 and X7 do not have a significant impact on $X 4$, but affect $X 5$.

The amount of equity capital depends on the amount of net profit (X5), part of which (retained earnings) is allocated to the formation of equity capital, and private investments (X8).

Borrowed and attracted capital for small and medium-sized enterprises is largely formed at the expense of bank loans (23-33\% of the amount of borrowed and attracted funds during 2014-2018), the amount of which and their expenses depend on the interest rate on loans for support for small and medium-sized businesses (G5). Additionally, the amount of borrowed and attracted capital depends on the volume of public investment (indicators G8, G9), private investments (X8) and government subsidies (indicator G7).

Indicators of state tax support (G1-G4) have a significant impact on the volume of net profit (X5).

According to statistical studies [76], the main factors constraining the activities of small and medium-sized enterprises throughout the entire period are the uncertainty of the economic situation (this factor was the main constraint for 61\% of SMEs in 2018); high inflation rate in the country (58\%); high percentage of commercial loans (54\%); lack of own financial resources (49\%). Nowadays, the COVID-19 pandemic comes to the fore among other uncertainty factors, which has provoked a record drop for the period of the RSBI calculation (2014-2020) [19].

In connection with the list of dominant constraining factors, the model of the influence of government support on the SME standing is supplemented with the indicator of COVID-19 propagation intensity (indicator X9), which will reflect the impact of the COVID-19 pandemic on the state of small and medium-sized businesses (indicator $Y$ ) in the model and act as the main controlling factor, which is destabilizing in nature, when determining the effectiveness of government support.

The model is also supplemented with indicators characterizing the level of inflation: the producer price index (X10), which affects the production costs of enterprises, and the consumer price index (X11), which affects the income of enterprises by amending the purchasing power of the population that is the main consumer of goods and services of small and medium-sized entities.

The remaining constraints of the development of small and medium-sized businesses are taken into account through the indicators of the volumes of equity capital, and borrowed and attracted funds of enterprises (indicators $X 6, X 7$ ).

The RSBI is directly influenced by indicators $X 5-X 7$ and $X 9$.

The statistically confirmed causalities are structured using a cognitive model that reflects the impact of government support tools on the economic development of small and medium-sized businesses (Figure 1). 


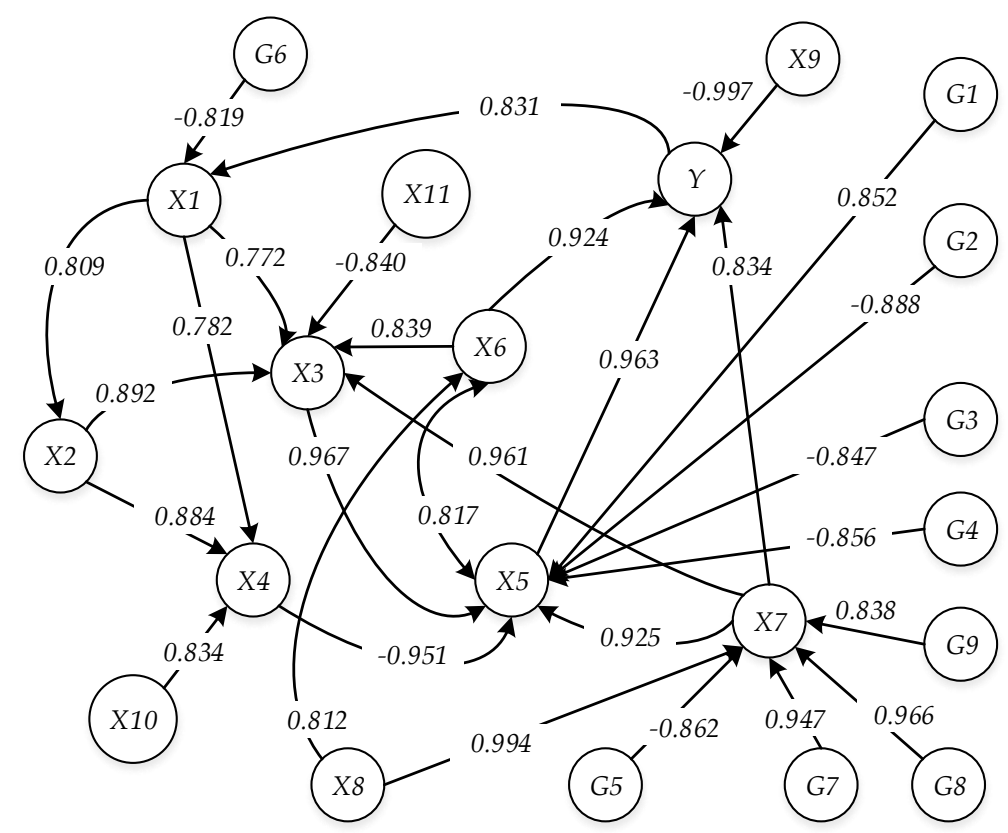

Figure 1. Cognitive model of the impact of government support tools on the economic development of SMEs in Russia during the pandemic.

To determine the strength of the influence of government support indicators (G1-G9) on the level of business activities of small and medium-sized businesses, the chains of the intermittent influence on the resulting indicator are determined on the basis of the built cognitive model. These chains reflect the direction of the influence of government support indicators on the resulting indicator by a directed graph, which is a cognitive model. The strength of the influence is defined as the percentage change in indicator $Y$ when each of the indicators G1-G9 changes by 1\%. The results are shown in Table 3.

The amendments of the resulting indicators were calculated for all chains of the intermittent actions. The deviation of the calculated values from the average within the scope of each of the government support instruments did not exceed 5\%. This fact, as well as the use of only statistically significant (according to the Granger test) causalities between indicators at $p=0.05$ with a probability of $95 \%$, indicated the adequacy of the obtained results of intermittent simulation. The cumulative value of the amendment of indicator $Y$ under the intermittent influence was calculated as the arithmetic mean over the chains of the intermittent actions within each of the government support tools.

Indicator G6 was an exception; its amendment had an opposite effect on the SME business activity index along different chains of intermittent actions. This is explained by the fact that the growth of indicator X1 (the dynamics of which depend on the dynamics of indicator G6), on the one hand, contributes to the growth of enterprise income, and on the other hand, to the growth of expenses. Therefore, the cumulative effect of the impulse in terms of indicator $G 6$ was calculated as the sum of the positive and negative impacts of its increase on indicator $Y$. 
Table 3. Intermittent assessment of the power of the influence of government support tools on the level of Russian SME business activities during a pandemic.

\begin{tabular}{|c|c|c|}
\hline $\begin{array}{l}\text { Government Support } \\
\text { Indicators }\end{array}$ & Chain of Intermittent Actions & $\begin{array}{l}\text { Changes in Indicator } Y \text { under the } \\
\text { Intermittent Influence, } \%\end{array}$ \\
\hline G1, million RUB & $G 1 \rightarrow X 5 \rightarrow Y$ & 0.820 \\
\hline G2, units & $G 2 \rightarrow X 5 \rightarrow Y$ & -0.855 \\
\hline G3, units & $G 3 \rightarrow X 5 \rightarrow Y$ & -0.815 \\
\hline G4, million RUB & $G 4 \rightarrow X 5 \rightarrow Y$ & -0.824 \\
\hline \multirow{3}{*}{ G5, \% per annum } & $G 5 \rightarrow X 7 \rightarrow X 5 \rightarrow Y$ & \multirow{3}{*}{-0.753} \\
\hline & $G 5 \rightarrow X 7 \rightarrow Y$ & \\
\hline & $G 5 \rightarrow X 7 \rightarrow X 3 \rightarrow X 5 \rightarrow Y$ & \\
\hline \multirow{4}{*}{ G6, units } & $G 6 \rightarrow X 1 \rightarrow X 2 \rightarrow X 3 \rightarrow X 5 \rightarrow Y$ & \multirow{4}{*}{-0.004} \\
\hline & $G 6 \rightarrow X 1 \rightarrow X 2 \rightarrow X \rightarrow X 5 \rightarrow Y$ & \\
\hline & $G 6 \rightarrow X 1 \rightarrow X 3 \rightarrow X 5 \rightarrow Y$ & \\
\hline & $G 6 \rightarrow X 1 \rightarrow X 4 \rightarrow X 5 \rightarrow Y$ & \\
\hline \multirow{3}{*}{ G7, billion RUB } & $G 7 \rightarrow X 7 \rightarrow X 5 \rightarrow Y$ & \multirow{3}{*}{0.827} \\
\hline & $G 7 \rightarrow X 7 \rightarrow Y$ & \\
\hline & $G 7 \rightarrow X 7 \rightarrow X 3 \rightarrow X 5 \rightarrow Y$ & \\
\hline \multirow{3}{*}{ G8, billion RUB } & $G 8 \rightarrow X 7 \rightarrow X 5 \rightarrow Y$ & \multirow{3}{*}{0.844} \\
\hline & $G 8 \rightarrow X 7 \rightarrow Y$ & \\
\hline & $G 8 \rightarrow X 7 \rightarrow X 3 \rightarrow X 5 \rightarrow Y$ & \\
\hline \multirow{3}{*}{ G9, billion RUB } & $G 9 \rightarrow X 7 \rightarrow X 5 \rightarrow Y$ & \multirow{3}{*}{0.767} \\
\hline & $G 9 \rightarrow X 7 \rightarrow Y$ & \\
\hline & $G 9 \rightarrow 7 \rightarrow X 3 \rightarrow X 5 \rightarrow Y$ & \\
\hline
\end{tabular}

The results of intermittent simulation indicate that:

- with an increase in the amount of deferred tax/duty payments by $1 \%$ relative to the level of 2018 , the RSBI increases by $0.820 \%$;

- $\quad$ with a decrease in the number of on-site tax audits by $1 \%$ it will increase by $0.855 \%$;

- with a decrease in the number of cameral tax audits by $1 \%$ it will increase by $0.815 \%$;

- with a decrease in the amount of insurance premium for compulsory social insurance by $1 \%$ it will increase by $0.824 \%$;

- $\quad$ with a decrease in interest on loans by $1 \%$ it will increase by $0.753 \%$;

- with a decrease in the number of enterprises that went bankrupt at the initiative of creditors by $1 \%$ it will increase by $0.004 \%$;

- with an increase in the volume of subsidies allocated from the federal budget for government support of small and medium-sized businesses by $1 \%$ it will increase by $0.827 \%$;

- with an increase in the volume of investments at the expense of budget funds in equity capital of small and medium-sized businesses by $1 \%$ it will increase by $0.844 \%$;

- with an increase in investment in equity capital of small and medium-sized businesses at the expense of state non-budgetary funds by $1 \%$ it will increase by $0.767 \%$.

The results obtained indicate that tax instruments of state regulation and government funding (subsidies and investments) make the indicator of SMEs' development most elastic.

During a pandemic, SMEs' solvency decreases, which leads to a violation of payment discipline with counterparties and the occurrence of fines and penalties. It is also possible that, during tax audits, 
an inspector may mistakenly accept a company that has gone bankrupt for objective reasons as a one-day company. Therefore, an increase in the number of tax audits during periods of instability results in unreasonable fines and decreased business activities of SMEs.

As a result of companies' insolvency, a problem occurs with the payment of taxes and fees and insurance contributions for compulsory social insurance. In this case, tax payment deferral and insurance premium holidays allow for avoiding additional penalties. Additionally, the funds that should be spent on paying taxes, fees and insurance premiums can be invested in expanded reproduction intended to overcome the negative impact of the pandemic. Subsidies allocated from the federal budget to support small and medium-sized businesses and investments in fixed assets of small and medium-sized businesses at the expense of budget funds may also be funds for expanded reproduction.

The monetary factor, an interest rate to support small and medium-sized businesses, demonstrates less efficiency for the development of SMEs than tax instruments and government funding. Nonetheless, a decreased interest rate reduces the financial costs of enterprises and, with the effective use of credit funds, can partially resume the business activities of enterprises.

A moratorium on bankruptcy filings initiated by creditors is the least effective tool for supporting SMEs; this measure is unable to solve problems with solvency and, in the absence of reserves for solvency restoring, it will only delay companies' bankruptcy.

Since 12.05.2020, the non-working day regime in Russia has been canceled and the basic sectors of the economy have restored their operations, despite the continuation of restrictions on the prohibition of mass events, and restrictions concerning passenger traffic [89]. With a view to the cancellation of the non-working day regime, the value of indicator $t_{2}$ in May was 50 days, and $t_{2}=0$ in the following months. The value of indicator $t_{1}$ continued to grow as a result of the constant increase in the number of cases in the world and the extension of quarantine in Europe, Asia and America [90]. Taking into account the dynamics of indicator X9, the correlation coefficient between this indicator and the RSBI, as well as the scenario of virus proliferation, according to which the pandemic will last until the end of 2020, when the vaccine against COVID-19 will be tested [91,92], the predicted RSBI values were obtained, as shown in Figure 2.

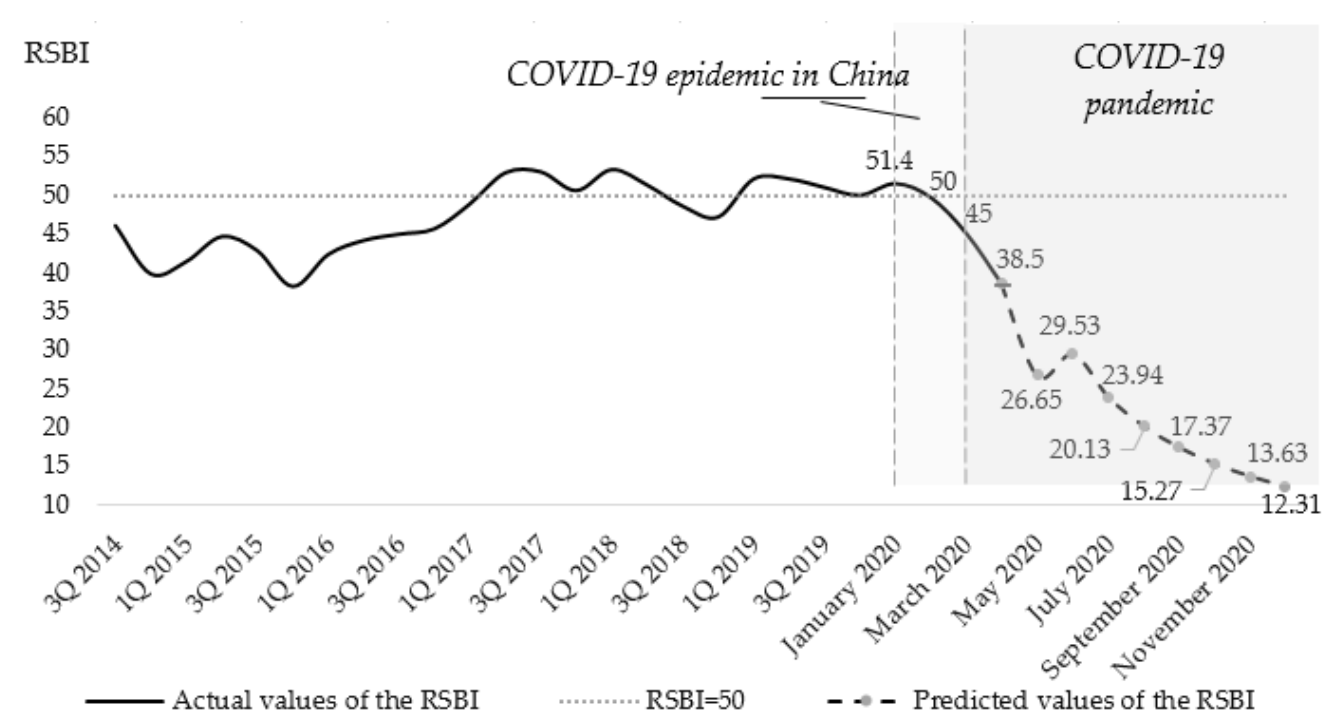

Figure 2. Dynamics of actual and predicted values of the Russia Small Business Index (RSBI) with regard to the intensity of the COVID-19 proliferation.

The predicted value of the index at the end of May 2020 will be 26.65 points in the absence of the implementation of government measures aimed at supporting entrepreneurship; in June, as a result of the abolition of restrictions in Russia, the indicator was predicted to increase to 29.53; in July, under the influence of quarantine in the world, which remains the main destabilizing factor in the development 
of small and medium-sized businesses, the RSBI was predicted to decrease to 23.94 with a subsequent decrease to 12.31 at the end of 2020.

To soften the negative impact of the pandemic on small and medium-sized businesses through instrument G1, the amount of deferred payments (installment liabilities) should increase to the amount of RUB 3,677,698.69 as a result of deferrals for small and medium-sized entrepreneurship. In this study, the softening of the negative impact of the pandemic aims to achieve RSBI $=50$, a further increase which will indicate the growth of business activities of small and medium-sized businesses [19].

When using instrument G4, the total amount of insurance premiums for compulsory social insurance going into the budget should decrease by $91.45 \%$ compared to 2018 .

Tax audits are able to stabilize the small and medium-sized business sector in Russia with a decrease in their number by $88.14 \%$ for on-site tax audits or by $92.45 \%$ for office tax audits compared to 2018 .

Indicators G2-G4 reflect the number of audits and the amount of income of all business entities (not only of small and medium-sized enterprises). The turnover of SMEs amounts to $20.2 \%$ of the total turnover of all business entities [10]; accordingly, the amount of insurance premiums of small and medium-sized enterprises, and the number of tax audits, are approximately at this level of the general indicators. In this regard, a decrease in indicators G2-G4 to the target values at the expense of small and medium-sized businesses is impossible. This indicates the need to use tax support tools in combination with other government support measures aimed at overcoming the negative consequences of the impact of the COVID-19 pandemic on the SME sector.

The interest rate that is applied to industries affected by the COVID-19 pandemic, and set by the government at $3.5 \%$, can keep the RSBI at a level of 17.99 points.

With regard to the factor of the COVID-19 proliferation intensity, the power of influence of which is increasing as a result of the further increase in the number of cases in Russia and in the world, and the continuation of quarantine in Russia, the moratorium on bankruptcy of enterprises initiated by creditors is also has low effectiveness. A complete ban on bankruptcies initiated by creditors will contribute to the growth of the RSBI to 12.36 points.

State funding is able to stabilize the business activity of small and medium-sized businesses by increasing the volume of government subsidies (G7) by 1.91 times, the volume of investments in equity capital of small and medium-sized businesses at the expense of budget funds (G8) by 1.89 times and the volume of investments in equity capital of SMEs at the expense of state non-budgetary funds (G9) by 1.98 times. The effectiveness of tools G1-G9 is calculated based on their ability to stabilize the business activities of small and medium-sized businesses in a pandemic when using each tool separately.

\section{Discussion}

In the current conditions, the duration of the pandemic proliferation and strict quarantine measures of self-isolation exert a decisive influence on the operation of SMEs in Russia and throughout the world, which was proved in the framework of this study, and was also repeatedly noted in earlier publications of numerous scholars $[22,27,44,46,47]$. This factor became fundamental in determining the prognostic trend of SMEs' development by the end of 2020. We proposed a cognitive model that makes it possible to substantiate the specific features of the COVID-19 impact on Russian SMEs' operations and the effectiveness of the implementation of the anti-crisis measures taken by the government. Unlike other studies [27], the Granger statistics and calculated values of paired coefficients of correlation enabled us to determine a quantitative assessment of the degree of influence of current organizational and financial measures of government support for entrepreneurship. This makes it possible to assess the priority and feasibility of the organizational measures to support SMEs, to level the subjectivity and formality of the anti-crisis policy and to increase its effectiveness in conditions of complete uncertainty.

The advantage of the proposed approach is the use of all chains of intermittent actions of the impact of indicators G1-G9 in the calculations, enabling us to take into account the complex influence of government support tools on the level of business activities of small and medium-sized businesses in Russia. This, in turn, made it possible to forecast the development of Russian SMEs in the short 
term. The obtained predicted values of the RSBI provide a comprehensive assessment of the current effectiveness of the anti-crisis measures and the predictive level of their return on efforts. This study made it possible to substantiate recommendations for improving effectiveness and responding to the crisis and restoring the government anti-crisis policies, so that small and medium-sized businesses can receive effective and timely support, and continue their development owing to effective solutions.

It is worth noting that the effective support of the government for SMEs' life in Russia should be aimed at increasing and maintaining the innovative activities of enterprises. Experience has shown that the vulnerability of this sector of the economy consists not only in limited resources, but also in a relatively low level of innovation potential. It should be especially emphasized that the COVID-19 pandemic has once again demonstrated the extreme importance and need for innovative development [66]. After all, the companies that actively introduced various digital technologies and solutions were able to survive the crisis more easily than companies that are only at the beginning of the digital path [66]. It is advisable for the SME sector in modern conditions to introduce and develop two approaches to innovation: intra-corporate and open innovations. Intra-corporate innovation is most often aimed at optimizing internal processes and developing a digital strategy [68]. This strategy should focus on creating digital platforms, ecosystems, operating models and customer offerings, and leverage artificial intelligence and digital transformation programs.

The open innovation model should be used by SMEs to find new technologies on the market for solving internal problems of the enterprise [68-71]. The transformation of firms' processes becomes particularly relevant in this aspect; these processes should be transformed in such a way to enable the support of employees' initiatives regarding the birth of new ideas in the directions indicated by top management. With minimal opportunities for generating financial resources and reducing budgets to search for new technologies, the introduction of such an approach into the practice of SMEs may be especially in demand. During the period of COVID-19, the ability to reduce costs and introduce technologies aimed at the rapid adaptation of production processes in SMEs is the main driver of innovation.

It should be emphasized that our findings have certain limiting aspects. Thus, the formulated recommendations for increasing the effectiveness of supporting organizational measures for the development of SMEs during the COVID-19 epidemic can only be applied for the conditions of Russian business functioning. However, this can serve as a positive aspect of the study, since the specific features of the current situation in the economy of a particular country were taken into account, which increases the reliability and objectivity of scientific results. The disadvantage of this study is the use of indicators of Russian SMEs' development for determining the correlation dependences to assess the effectiveness of the government anti-crisis policies for 2014-2018 in view of the lack of official statistics, which are published a year later. However, this factor is leveled by using the correlation coefficients between indicators $X 9$ and $Y$, calculated on the basis of monthly data for January-April 2020 when forecasting the RSBI dynamics.

\section{Conclusions}

Thus, within the framework of this study, the tasks of scientific research were completely solved to systematize the fundamental factors of the destructive impact exerted by the COVID-19 pandemic propagation on SME operations in Russia. The effectiveness of state support instruments was also empirically assessed in the context of an unstable economic environment for SMEs.

According to the research forecasts made, without the implementation of the anti-crisis package of government support, the business activity of SMEs may fall by the end of 2020 by 39.09 points relative to the beginning of the year. It is predicted that the RSBI will fall to the level of 12.31 points in December 2020. The results obtained indicate that comprehensive measures should be implemented, including tax, administrative, banking and financial support for small and medium-sized businesses for leveling the negative impact of the COVID-19 pandemic. With regard to the pandemic intensity as the main destructive factor in the development of small and medium-sized businesses at this stage, 
the effectiveness of government support policies was assessed. It was determined that in case measures such as a moratorium on conducting tax audits, a moratorium on bankruptcy filing initiated by creditors, insurance premium reduction, deferred tax payments (installment liabilities) and reduction of the bank interest rate to $3.5 \%$, as provided by the Russian Government, are not implemented in a complex, they are unable to neutralize the negative impact of the COVID-19 pandemic. State funding is more effective and capable of restoring business activities of small and medium-sized businesses, but the volume of state funding should increase by 1.89-1.98 times. Therefore, to level the negative impact of the COVID-19 pandemic, comprehensive measures should be implemented, including tax, administrative, banking and financial support for small and medium-sized businesses. Our findings are based on evidence collected from a thorough review of the scientific and analytical literature on the research topic.

Cognitive and impulse modeling made it possible to determine the effectiveness of public policy instruments based on empirical substantiation in quantitative terms. An objective assessment of measures aimed at supporting the SMEs' business activities in the face of a shock to market supply and demand creates the basis for ensuring a balanced life of enterprises. This, in turn, will be crucial for the economic growth recovery after the crisis.

Author Contributions: Conceptualization, E.R. and L.Y.; Data curation, E.R.; Formal analysis, E.R.; Funding acquisition, E.R.; Investigation, E.R.; Methodology, E.R.; Project administration, E.R.; Resources, E.R.; Software, E.R.; Supervision, E.R.; Validation, E.K., M.K. and V.S.; Visualization, L.Y.; Writing-original draft, E.R.; Writing - review and editing, E.R. All authors have read and agreed to the published version of the manuscript.

Funding: This research received no external funding.

Conflicts of Interest: The author declares no conflict of interest.

\section{References}

1. Obi, J.; Ibidunni, A.S.; Tolulope, A.; Olokundun, M.A.; Amaihian, A.B.; Borishade, T.T.; Fred, P. Contribution of small and medium enterprises to economic development: Evidence from a transiting economy. Data Brief 2018, 18, 835-839. [CrossRef]

2. Ndiaye, N.; Razak, L.A.; Nagayev, R.; Ng, A. Demystifying small and medium enterprises' (SMEs) performance in emerging and developing economies. Borsa Istanb. Rev. 2018, 18, 269-281. [CrossRef]

3. Prasetyo, P.E.; Kistanti, N.R. Human capital, institutional economics and entrepreneurship as a driver for quality \& sustainable economic growth. Entrep. Sustain. Issues 2020, 7, 2575-2589.

4. Gamidullaeva, L.A.; Vasin, S.M.; Wise, N. Increasing small- and medium-enterprise contribution to local and regional economic growth by assessing the institutional environment. J. Small Bus. Enterp. Dev. 2020, 27, 259-280. [CrossRef]

5. Ronda, L.; Valor, C.; Abril, C. How small traditional businesses can become attractive employers: A means-end analysis. J. Small Bus. Manag. 2020, 58, 362-389. [CrossRef]

6. Breitzman, A.; Hicks, D. An Analysis of Small Business Patents by Industry and Firm Size. Fac. Sch. Coll. Sci. Math. 2008, 12. Available online: https://pdfs.semanticscholar.org/6273/feb95407897f374761687cc5596b43b2c878.pdf? _ga $=2.22497467 .1806168906 .1591278231-667158733.1588269937$ (accessed on 21 May 2020).

7. Herr, H.; Nettekoven, Z.M. The Role of Small and Medium-sized Enterprises in Development. What Can Be Learned from the German Experience? Friedrich Ebert Stiftung. 2017. Available online: https:/library.fes.de/ pdf-files/iez/14056.pdf (accessed on 25 May 2020).

8. EC. Country Report Finland 2019. 2019 European Semester: Assessment of progress on structural reforms, Prevention and Correction of Macroeconomic Imbalances, and Results of In-Depth Reviews under Regulation (EU) No 1176/2011. 2019. Available online: https:/ec.europa.eu/info/sites/info/files/file_import/2019-europeansemester-country-report-finland_en.pdf (accessed on 22 May 2020).

9. Stolypin, P.A.; Institute for the Economy of Growth. Small and Medium-Sized Business Sector: Russia and the World. 2018. Available online: http://stolypin.institute/novosti/sektor-malogo-i-srednego-predprinimatelstvarossiya-i-mir/ (accessed on 28 May 2020).

10. RBC. Rosstat Recorded a Decrease in the Share of Small Business in the Economy. 2020. Available online: https://www.rbc.ru/economics/28/01/2020/5e2eda219a79473c798d3692 (accessed on 22 May 2020). 
11. Government of Russia. National Project "Small and Medium-Sized Entrepreneurship and Support for Individual Entrepreneurial Initiatives". 2018. Available online: http://government.ru/rugovclassifier/864/ events/ (accessed on 25 May 2020).

12. Government of Russia. On the Approval of the Strategy for the Development of Small and Medium-Sized Enterprises until 2030. 2016. Available online: http://government.ru/docs/23354/ (accessed on 25 May 2020).

13. Expert, RA. Forecast for Lending to Small and Medium-Sized Businesses in Russia for 2020: Records behind. 2020. Available online: https://www.raexpert.ru/researches/banks/msb_2019 (accessed on 28 May 2020).

14. Kraemer-Eis, H.; Botsari, A.; Gvetadze, S.; Lang, F.; Torfs, W. European Small Business Finance Outlook: June 2019; EIF Working Paper, No. 2019/57; European Investment Fund (EIF): Luxembourg. Available online: https://www.econstor.eu/bitstream/10419/201544/1/1670468127.pdf (accessed on 21 May 2020).

15. SME Corporation. Concessional Lending Programs for Small and Medium-Sized Businesses, Stimulating Lending to SMEs. Available online: https://corpmsp.ru/bankam/programma_stimulir/ (accessed on 21 May 2020).

16. Government of Russia. The Passport of the National Project "Small and Medium-Sized Entrepreneurship and Support for Individual Entrepreneurial Initiatives" Has Been Published. 2019. Available online: http: //government.ru/info/35563/ (accessed on 23 May 2020).

17. PwC. Paying Taxes 2020: Overall Ranking and Data Tables. Available online: https://www.pwc.com/gx/en/ services/tax/publications/paying-taxes-2020/overall-ranking-and-data-tables.html (accessed on 28 May 2020).

18. Arenina, K. The Number of Small and Medium-Sized Companies in Russia Decreases by 6-10\% per Year. The Bell. 2020. Available online: https:/thebell.io/chislo-malyh-i-srednih-kompanij-v-rossii-sokrashhaetsyana-6-10-v-god (accessed on 30 May 2020).

19. PSB. The Russia Small Business Index (RSBI). Available online: https://www.psbank.ru/-/media/PSB-1_2/ OnlineServices/RSBI-_2020_aprel_presentation.pdf (accessed on 21 May 2020).

20. RuBezh. Russia Small Business Index Fell to Lowest Since 2014. Available online: https://ru-bezh.ru/kompaniii-ryinki/news/20/05/19/indeks-delovoj-aktivnosti-malogo-i-srednego-biznesa-upal-do-mini (accessed on 21 May 2020).

21. Interfax. Kudrin Predicted a Jump in Unemployment in Russia Amid the Crisis to $10 \%$ in the Worst Case. Available online: https://www.interfax.ru/russia/706027 (accessed on 29 May 2020).

22. Zemtsov, S.; Tsareva, Y. Trends in the Development of the Sector of Small and Medium-Sized Enterprises in the Context of a Pandemic and Crisis. Monit. Econ. Situat. Russ. Trends Chall. Socio Econ. Dev. 2020, 10, 155-166. Available online: https://www.iep.ru/upload/iblock/543/16.pdf (accessed on 26 May 2020).

23. Barinova, V. A hole in the GDP: What Does the Death of Small Business in Russia Threatens the Economy with. Forbes. 2020. Available online: https://www.forbes.ru/biznes/399389-dyra-v-vvp-chem-grozit-ekonomikegibel-malogo-biznesa-v-rossii (accessed on 26 May 2020).

24. Dimson, J.; Mladenov, Z.; Sharma, R.; Tadjeddine, K. COVID-19 and European Small and Medium-Size Enterprises: How They are Weathering the Storm. McKinsey \& Company. 2020. Available online: https://www.mckinsey.com/industries/public-and-social-sector/our-insights/covid-19-and-europeansmall-and-medium-size-enterprises-how-they-are-weathering-the-storm (accessed on 4 November 2020).

25. Deliu, D. The Intertwining between Corporate Governance and Knowledge Management in the Time of Covid-19-A Framework. Emerg. Trends Mkt. Manag. 2020, 1, 93-110.

26. Eggers, F. Masters of disasters? Challenges and opportunities for SMEs in times of crisis. J. Bus. Res. 2020, 116, 199-208. [CrossRef]

27. Bouey, J. Assessment of COVID-19's Impact on Small and Medium-Sized Enterprises. Implications from China. RAND Corporation. 2020. Available online: https://www.rand.org/pubs/testimonies/CT524.html (accessed on 23 May 2020).

28. Lesser, R.; Reeves, M. 5 Priorities for Leaders in the New Reality of COVID-19. World Economic Forum. 2020. Available online: https://www.weforum.org/agenda/2020/05/5-things-leaders-succeed-new-realitycoronavirus/ (accessed on 4 November 2020).

29. CSR. Business Outlined the Problems to be Faced after the Crisis. Available online: https://www.csr.ru/ru/ news/biznes-oboznachil-problemy-s-kotorymi-stolknetsya-posle-krizisa/ (accessed on 27 May 2020).

30. Government of Russia. Resolution No. 434 dated 3 April 2020. On the Approval of the List of the Russian Economy Sectors Most Affected by the Worsening Situation as a Result of the Spread of the New Coronavirus Infection. Available online: https://ppt.ru/docs/postanovlenie/pravitelstvo/n-434-231476 (accessed on 27 May 2020). 
31. The State Duma. Federal Law Dated 03.04.2020 No. 106-FZ. On Amendments to the Federal Law “On the Central Bank of the Russian Federation (Bank of Russia)" and Certain Legislative Acts of the Russian Federation as Regards the Specifics of Amending the Terms of the Credit Agreement and Loan Agreement. Available online: http://publication.pravo.gov.ru/Document/View/0001202004030061?index=0\&rangeSize=1 (accessed on 21 May 2020).

32. The State Duma. Federal Law Dated 01.04.2020 No. 102-FZ. On Amendments to Parts One and Two of the Tax Code of the Russian Federation and Certain Legislative Acts of the Russian Federation. Available online: https://ppt.ru/docs/fz/102-fz-231279 (accessed on 21 May 2020).

33. Tinkoff. Tinkoff CoronaIndex: In May, Small and Medium-Sized Businesses Began to Come Back to Life. 2020. Available online: https://www.tinkoff.ru/about/news/01062020-tinkoff-coronaindex-business-is-comingback-to-life/ (accessed on 30 May 2020).

34. Republic. Analysts Announced the Threat of Closure of Every Fifth Small and Medium-Sized Enterprise in Russia. Available online: http://rk.karelia.ru/ekonomika/analitiki-zayavili-ob-ugroze-zakrytiya-kazhdogopyatogo-malogo-i-srednego-predpriyatiya-v-rossii/ (accessed on 30 May 2020).

35. National Action Plans on Business and Human Rights. Small \& Medium-Sized Enterprises. Available online: https://globalnaps.org/issue/small-medium-enterprises-smes/ (accessed on 21 May 2020).

36. Lemes, A.; Machado, T. SMEs and Their Space in the Latin American Economy. 2007. Available online: http://www.eumed.net/eve/resum/07-enero/alb.htm (accessed on 21 May 2020).

37. Amankwah-Amoah, J.; Khan, Z.; Wood, G. COVID-19 and business failures: The Paradoxes of Experience, Scale, and Scope for Theory and Practice. Eur. Manag. J. 2020. [CrossRef]

38. Jenson, H.B. How did "flatten the curve" become "flatten the economy?". Perspect. USA Asian J. Psychiatry 2020, 51, 102165. [CrossRef] [PubMed]

39. Shafi, M.; Liu, J.; Ren, W. Impact of COVID-19 pandemic on micro, small, and medium-sized Enterprises operating in Pakistan. Res. Glob. 2020, 2, 100018. [CrossRef]

40. Vasiljeva, M.; Neskorodieva, I.; Ponkratov, V.; Kuznetsov, N.; Ivlev, V.; Ivleva, M.; Maramygin, M.; Zekiy, A. A Predictive Model for Assessing the Impact of the COVID-19 Pandemic on the Economies of Some Eastern European Countries. J. Open Innov. Technol. Mark. Complex. 2020, 6, 92. [CrossRef]

41. Sharma, P.; Leung, T.Y.; Kingshott, R.P.J.; Davcik, N.S.; Cardinali, S. Managing uncertainty during a global pandemic: An international business perspective. J. Bus. Res. 2020, 116, 188-192. [CrossRef] [PubMed]

42. Kulachinskaya, A.; Akhmetova, I.G.; Kulkova, V.Y.; Ilyashenko, S.B. The Challenge of the Energy Sector of Russia during the 2020 COVID-19 Pandemic through the Example of the Republic of Tatarstan: Discussion on the Change of Open Innovation in the Energy Sector. Open Innov. Technol. Mark. Complex. 2020, 6, 60. [CrossRef]

43. Ponkratov, V.; Kuznetsov, N.; Bashkirova, N.; Volkova, M.; Alimova, M.; Ivleva, M.; Vatutina, L.; Elyakova, I. Predictive Scenarios of the Russian Oil Industry; with a Discussion on Macro and Micro Dynamics of Open Innovation in the COVID 19 Pandemic. Open Innov. Technol. Mark. Complex. 2020, 6, 85. [CrossRef]

44. Eichenbaum, M.S.; Rebelo, S.; Trabandt, M. The Macroeconomics of Epidemics. NBER Working Paper No. 26882. 2020. Available online: https://www.nber.org/papers/w26882.pdf (accessed on 25 May 2020).

45. Guan, D.; Wang, D.; Hallegatte, S.; Davis, S.J.; Huo, J.; Li, S.; Bai, Y.; Lei, T.; Xue, Q.; Coffman, D.; et al. Global supply-chain effects of COVID-19 control measures. Nat. Hum. Behav. 2020, 4, 577-587. [CrossRef]

46. McKibbin, W.; Fernando, R. The Global Macroeconomic Impacts of COVID-19: Seven Scenarios. 2020. Available online: https://www.brookings.edu/wp-content/uploads/2020/03/20200302_COVID19.pdf (accessed on 23 May 2020).

47. Caracciolo, G.; Cingano, F.; Ercolani, V.; Ferrero, G.; Hassan, F.; Papetti, A.; Tommasino, P. Covid-19 and Economic Analysis: A Review of the Debate. Banca D'italia. Lit. Rev. 2020, 2. Available online: https: //www.bancaditalia.it/media/notizie/2020/Covid-literature-newsletter-n2.pdf (accessed on 26 May 2020).

48. Li, T. A SWOT analysis of China's air cargo sector in the context of COVID-19 pandemic. J. Air Transp. Manag. 2020, 88, 101875. [CrossRef]

49. Akande-Sholabi, W.; Adebisi, Y.A.; Bello, A.; Ilesanmi, O.S. COVID-19 in Nigeria: Is the pharmaceutical sector spared? Public Health Pract. 2020, 1, 100044. [CrossRef]

50. Rowan, N.J.; Galanakis, C.M. Unlocking challenges and opportunities presented by COVID-19 pandemic for cross-cutting disruption in agri-food and green deal innovations: Quo Vadis? Sci. Total Environ. 2020, 748, 141362. [CrossRef] [PubMed] 
51. Kennelly, B.; O'Callaghan, M.; Coughlan, D.; Cullinan, J.; Doherty, E.; Glynn, L.; Moloney, E.; Queally, M. The COVID-19 pandemic in Ireland: An overview of the health service and economic policy response. Health Policy Technol. 2020. [CrossRef] [PubMed]

52. Lee, J.-W.; McKibbin, W. Globalization and Disease: The Case of SARS. Asian Econ. Pap. 2004, 3, 113-131. [CrossRef]

53. Evans, D.K.; Goldstein, M.; Popova, A. The Next Wave of Deaths from Ebola? In The Impact of Health Care Worker Mortality; Policy Research Working Paper, no. WPS 7344; World Bank Group: Washington, DC, USA, 2015.

54. Brown, R.; Rocha, A. Entrepreneurial uncertainty during the Covid-19 crisis: Mapping the temporal dynamics of entrepreneurial finance. J. Bus. Ventur. Insights 2020, 14, e00174. [CrossRef]

55. Smith, R.D.; Keogh-Brown, M.R.; Barnett, T. Estimating the economic impact of pandemic influenza: An application of the computable general equilibrium model to the UK. Soc. Sci. Med. 2011, 73, 235-244. [CrossRef]

56. Choi, S.-Y. Industry volatility and economic uncertainty due to the COVID-19 pandemic: Evidence from wavelet coherence analysis. Finance Res. Lett. 2020, 101783. [CrossRef]

57. Grida, M.; Mohamed, R.; Zaied, A.N.H. Evaluate the impact of COVID-19 prevention policies on supply chain aspects under uncertainty. Transp. Res. Interdiscip. Perspect. 2020, 8, 100240. [CrossRef]

58. Fernandes, N. Economic Effects of Coronavirus Outbreak (COVID-19) on the World Economy. 2020. Available online: https://papers.ssrn.com/sol3/papers.cfm?abstract_id=3557504 (accessed on 4 November 2020).

59. OECD. Coronavirus (COVID-19): SME Policy Responses. 2020. Available online: https://www. oecd.org/coronavirus/policy-responses/coronavirus-covid-19-sme-policy-responses-04440101/ (accessed on 4 November 2020).

60. Turner, J.; Akinremi, T. The business effects of pandemics-A rapid literature review. In ERC Insight Paper; Available online: https://www.enterpriseresearch.ac.uk/publications/the-business-effects-of-pandemics-arapid-literature-review/ (accessed on 4 November 2020).

61. Cheng, C. COVID-19 in Malaysia: Economic Impacts \& Fiscal Responses. Institute of Strategic and International Studies (ISIS) Malaysia. Policy Brief 2020, 1-20. Available online: https://www.isis.org.my/wpcontent/uploads/2020/06/POLICY-BRIEF_COVID-19-in-Malaysia.pdf (accessed on 4 November 2020).

62. Zheng, C.; Zhang, J. The impact of COVID-19 on the efficiency of microfinance institutions. Int. Rev. Econ. Financ. 2020, 71, 407-423. [CrossRef]

63. Alonso, A.D.; Kok, S.K.; Bressan, A.; O’Shea, M.; Sakellarios, N.; Koresis, A.; Solis, M.A.B.; Santoni, L.J. COVID-19, aftermath, impacts, and hospitality firms: An international perspective. Int. J. Hosp. Manag. 2020, 91, 102654. [CrossRef]

64. Ibarra, D.; Bigdeli, A.Z.; Igartua, J.I.; Ganzarain, J. Business Model Innovation in Established SMEs: A Configurational Approach. Open Innov. Technol. Mark. Complex. 2020, 6, 76. [CrossRef]

65. Jagongo, A. Strategic Resource Mobilization for Entrepreneurial Financing (A Review of Impediments for Growth of Women Owned Msmes in Kenya). In Proceedings of the 5th Business \& Management Conference, Rome, Italy, 5-8 April 2017; pp. 75-98. [CrossRef]

66. Papadopoulos, T.; Baltas, K.N.; Balta, M.E. The use of digital technologies by small and medium enterprises during COVID-19: Implications for theory and practice. Int. J. Inf. Manag. 2020, 55, 102192. [CrossRef] [PubMed]

67. Temitope, A.E. Change Management in Small and Medium Enterprises: Leveraging Information Technology. Int. J. Adv. Res. Comput. Sci. Technol. 2015, 3, 10-16.

68. Grama-Vigouroux, S.; Saidi, S.; Berthinier-Poncet, A.; Vanhaverbeke, W.; Madanamoothoo, A. From closed to open: A comparative stakeholder approach for developing open innovation activities in SMEs. J. Bus. Res. 2019. [CrossRef]

69. Mei, L.; Zhang, T.; Chen, J. Exploring the effects of inter-firm linkages on SMEs' open innovation from an ecosystem perspective: An empirical study of Chinese manufacturing SMEs. Technol. Forecast. Soc. Chang. 2019, 144, 118-128. [CrossRef]

70. Albats, E.; Alexander, A.; Mahdad, M.; Miller, K.; Post, G. Stakeholder management in SME open innovation: Interdependences and strategic actions. J. Bus. Res. 2019. [CrossRef]

71. De Marco, C.E.; Martelli, I.; Di Minin, A. European SMEs' engagement in open innovation When the important thing is to win and not just to participate, what should innovation policy do? Technol. Soc. Chang. 2020, 152, 119843. [CrossRef]

72. Government of Russia. On the Measures to Support Small and Medium-Sized Businesses and on the Organization of Lending to SMEs in the Context of the Coronavirus Infection Proliferation. 2020. Available online: http://government.ru/news/39291/ (accessed on 21 May 2020). 
73. RBC. The Authorities came up with a Scheme to Help Small Businesses during a Pandemic. Available online: https://www.rbc.ru/economics/25/03/2020/5e7b0b6c9a7947bf1ac40ded (accessed on 24 May 2020).

74. Federal Tax Service. Available online: https://analytic.nalog.ru/portal/index.ru-RU.htm (accessed on 21 May 2020).

75. Bank of Russia. Available online: http://www.cbr.ru/hd_base/ProcStav/IR_SRM/?UniDbQuery.Posted=True\& UniDbQuery.From=01.05.2014\&UniDbQuery.To=25.05.2020 (accessed on 21 May 2020).

76. Federal Resource. Available online: https://fedresurs.ru/?attempt=1 (accessed on 21 May 2020).

77. Federal State Statistics Service. Statistics. Available online: https://gks.ru/statistic (accessed on 21 May 2020).

78. Parshutina, I. Formation of Entrepreneurial Climate in Russia for Sustainable Development of Small Business. In Proceedings of the International Scientific and Practical Conference "Contemporary Issues of Economic Development of Russia: Challenges and Opportunities" (CIEDR 2018), Veliky Novgorod, Russia, 12-13 December 2018; pp. 142-152. [CrossRef]

79. Egorova, N.E.; Koroleva, E.A. Measurement of Mutual Trust Level between Small Enterprises and Banks. Adv. Soc. Sci. Educ. Hum. Res. 2019, 298, 565-567.

80. Chemodanova, O.; Grib, G. Problems of Development of Small and Medium Enterprise (SME) in Russia and Methods of Solving Them. Adv. Econ. Bus. Manag. Res. 2017, 32, 45-48.

81. Makarenko, E.N.; Chernysheva, Y.G.; Polyakova, I.A.; Makarenko, T.V. The Success Factors of Small Business. Int. J. Econ. Bus. Adm. 2019, VII, 280-288.

82. Kotane, I.; Kuzmina-Merlino, I. Analysis of Small and Medium Sized Enterprises' Business Performance Evaluation Practice at Transportation and Storage Services Sector in Latvia. Procedia Eng. 2017, 178, 182-191. [CrossRef]

83. Massaro, M.; Rubens, A.; Bardy, R.; Bagnoli, C. Antecedents to Export Performance and How Italian and Slovanian SME's Innovate during Times of Crisis. J. East. Eur. Cent. Asian Res. 2017, 4, 22. [CrossRef]

84. Šebestová, J.; Sroka, W. Sustainable development goals and SMEs decisions: Czech Republic vs. Poland. J. East. Eur. Cent. Asian Res. 2020, 7, 39-50. [CrossRef]

85. Zylla, E.; Hartman, L. State COVID-19 Data Dashboards. State Health and Value Strategies. 2020. Available online: https://www.shvs.org/state-covid-19-data-dashboards/ (accessed on 27 May 2020).

86. Chen, Z.-L.; Zhang, Q.; Lu, Y.; Guo, Z.-M. Distribution of the COVID-19 Epidemic and Correlation with Population Emigration from Wuhan, China. Chin. Med. J. 2020, 133. Available online: https://www.researchgate.net/publication/339626443_Distribution_of_the_COVID-19_epidemic_ and_correlation_with_population_emigration_from_Wuhan_China (accessed on 24 May 2020). [CrossRef]

87. Saba, A.I.; Elsheikh, A.H. Forecasting the prevalence of COVID-19 outbreak in Egypt using nonlinear autoregressive artificial neural networks. Process Saf. Environ. Prot. 2020, 141, 1-8. [CrossRef]

88. Support of Russia. Support Index RSBI. Available online: https://opora.ru/projects/indeks-opory-rsbi/ (accessed on 21 May 2020).

89. LB.ua. Russia to Start Exit from Quarantine from May 12. Available online: https://lb.ua/world/2020/05/11/ 457255_rossiya_nachnet_vihod_karantina_12.html (accessed on 29 May 2020).

90. OECD. Tackling Coronavirus (COVID-19). Contributing to a Global Effort. Available online: http://www. oecd.org/coronavirus/en/ (accessed on 27 May 2020).

91. Ferra.ru. Experts Calculated When the Coronavirus Pandemic May End in the World. Available online: https://www.ferra.ru/news/techlife/eksperty-podschitali-kogda-v-mire-mozhet-zakonchitsya-pandemiyakoronavirusa-24-05-2020.htm (accessed on 28 May 2020).

92. Glavcom. The European Union Gave a Forecast When the Vaccine Against Coronavirus Was Ready. Available online: https://glavcom.ua/ru/news/v-evrosoyuze-dali-prognoz-kogda-budet-gotova-vakcina-otkoronavirusa-679963.html (accessed on 28 May 2020).

Publisher's Note: MDPI stays neutral with regard to jurisdictional claims in published maps and institutional affiliations.

(C) 2020 by the authors. Licensee MDPI, Basel, Switzerland. This article is an open access article distributed under the terms and conditions of the Creative Commons Attribution (CC BY) license (http://creativecommons.org/licenses/by/4.0/). 